\title{
A habitat similarity model based on vague sets to assess Schizothorax prenanti spawning habitat
}

\section{Leilei Qin ${ }^{1}$, Kefeng $\mathrm{Li}^{1}$, Yong $\mathrm{Li}^{1}{ }^{*}$, Ruifeng Liang ${ }^{1}$, Mingqian Chen ${ }^{2}$, Ben R. Hodges ${ }^{3}$}

1 Institute of Ecology and Environment, State Key Laboratory of Hydraulics and Mountain

River Engineering, College of Water Resource \& Hydropower, Sichuan University, Chengdu, Sichuan, China.

2 Sichuan Environment \& Engineering Appraisal Center, Chengdu, Sichuan, China

3 Department of Civil, Architectural, and Environmental Engineering, University of Texas at Austin, Austin 78712, USA.

* Corresponding author

E-mail address: Liyong_scu@126.com 


\section{ABSTRACT}

Schizothorax prenanti (S. prenanti) is a second-class provincial protected endemic fish within the upper reaches of the Min River. The spawning season of $S$. prenanti extends from March to April. Habitat alteration and the construction of multistage dams have resulted in a rapid decline of the $S$. prenanti population. To assess the potential effects of a reduced flow volume on the $S$. prenanti spawning habitat area in downstream of dams, we combined River 2D and a habitat similarity evaluation model through the following steps. First, we conducted surveys of S. prenanti and the substrate composition in a natural habitat reach and a hydropower-affected reach. Second, hydraulic simulations were performed over a range of flows using River 2D. Third, vague sets of habitat variables were individually defined based on multi-expert opinions. Fourth, we estimated the weighted similarity of the $S$. prenanti spawning habitat using input variables (water depth, velocity) from River 2D. Fifth, we verified the model with S. prenanti survey data. Hydraulic simulations for velocity and depth yielded accuracies of approximately $84-97 \%$ and $81-98 \%$, respectively. The weighted similarity simulations showed that weighted similarity increased with the flow up to a threshold range of approximately $130-150 \mathrm{~m}^{3} / \mathrm{s}$; beyond this range, the weighted similarity decreased. The weighted similarity in the natural habitat reach was higher than in the restored reach at the same flow volume due to geography. The habitat similarity model provides restoration targets and thresholds for decision makers to develop a proactive conservation strategy for wetland management. 


\section{Key words:}

Schizothorax prenanti; vague sets; habitat similarity model; habitat restoration; ecological flow 


\section{Introduction}

Schizothorax prenanti (S. prenanti) is a second-class provincial protected endemic fish within the upper reaches of the Min River (Song, Z, et al., 2008; Ding, R.H., 1994). However, multistage dams have been constructed in the upper Min River, and these disturbances have altered historic hydro-geomorphic processes and the original hydraulic conditions of the habitat in these regions (Hou, 2010), resulting in a decline of available spawning areas for S. prenanti. To maintain appropriate habitat conditions for $S$. prenanti and other aquatic organisms to complete their life cycles, habitat restoration efforts should be conducted in the hydro-effected reaches. (Ahmadi-nedushan, et al., 2008, 2006; Dong, 2007; Wheaton, et al., 2004a, and 2004b).

The physical habitat structure is the primary determinant of species composition in river. The most important physical habitat variables include water depth, water velocity, cover and substrate composition. The protection and rehabilitation of the habitats of target species, such as juvenile Atlantic salmon, brown trout (Armstrong, 2003), Chinese sturgeon (Yang, 2007) and S. prenanti (Chen, 2013), have been widely studied in recent years. Tharme (Tharme, R E, 2003) and Leclerc (Leclerc, M, et al., 1995) reviewed different methods for environmental flow assessment, including traditional methods such as hydrological, hydraulic, habitat simulation and holistic approaches (Tharme, R E, 2003, 1996; Ahamadi-Nedushan, B, et al., 2006). Ahamadi-Nedushan and colleagues reviewed statistical methods for the evaluation of aquatic habitat suitability for in-stream flow assessment and reviewed habitat suitability indices 
to calculate the amount of weighted usable area (Ahamadi-Nedushan, B, et al., 2006).

Vague set theory (Gau and Buehrer, 1993) is an extension of classic fuzzy set theory (Zadeh, 1965) and is based on the central concept or membership functions (YE, 2007). In a previous study, Wheaton (2004) showed that appropriate riverbed restoration designs are produced by imitating the attributes of either a present-day or historical natural analogue. Compared with traditional habitat modeling, the fuzzy logic approach presents advantages in imitating historical natural analogues and dealing with the uncertainties that are often inherent in habitat modeling. Vague sets can be used as an alternative to habitat suitability curves, which are describe habitat requirements in habitat and holistic modeling (Lee, 2014; Moir, et. al., 2005; Hong, 2000; Bovee, 1986; Jorde, et al., 2001).

In this study, we combined River 2D, which predicts local variations in depth and velocity at a given flow, and a vague-based similarity evaluation that assesses habitat quality for fish using hydraulic indexes to assess the potential effects of a reduced flow volume on S. prenanti spawning habitat area in downstream of dams. This approach is illustrated by two case studies involving a reach of natural $S$. prenanti spawning habitat in the Weimen reach and a restoration reach downstream of the Jiangshe Dam. The study species and sites along the Min River (China) are introduced in Section 2.1, followed by an introduction to substrate evaluation (Section 2.2), description of the field measurements (Section 2.3), the ideas pertinent to the hydrodynamic model (Section 2.4) and the habitat similarity assessment model (Section 2. 5). The results may provide flow volume thresholds for $S$. prenanti spawning habitat for managers in the development of $S$. prenanti habitat restoration. 


\section{Materials and methods}

\subsection{Study sites and species}

S. prenanti is a native species of Min River and spawns in shallow areas with a rapid flow. Its spawning season extends from March to April in the upper Min River. In the present study, we selected a natural spawning site from the natural ecological reserve reach extending from the confluence of the Heishui and Min Rivers to Mao township $\left(31.75^{\circ}, 103.78^{\circ} \mathrm{E}\right.$ to $31.75^{\circ} \mathrm{N}$, $103.81^{\circ} \mathrm{E}$ ), which is located approximately $37 \mathrm{~km}$ upstream from the dam. The selected natural spawning site is presently undammed and remains undisturbed by streambed gravel mining and offers good natural spatial heterogeneity and pool riffle sequences. Downstream from this area, the Jiyu Dam, Tongzhong barrage and Jiangshe Dam are diversion hydropower stations. We selected a hydropower-affected reach of approximately $1 \mathrm{~km}$ downstream from the Jiangshe Dam. Details of the study reaches are provided in Figure 1. 


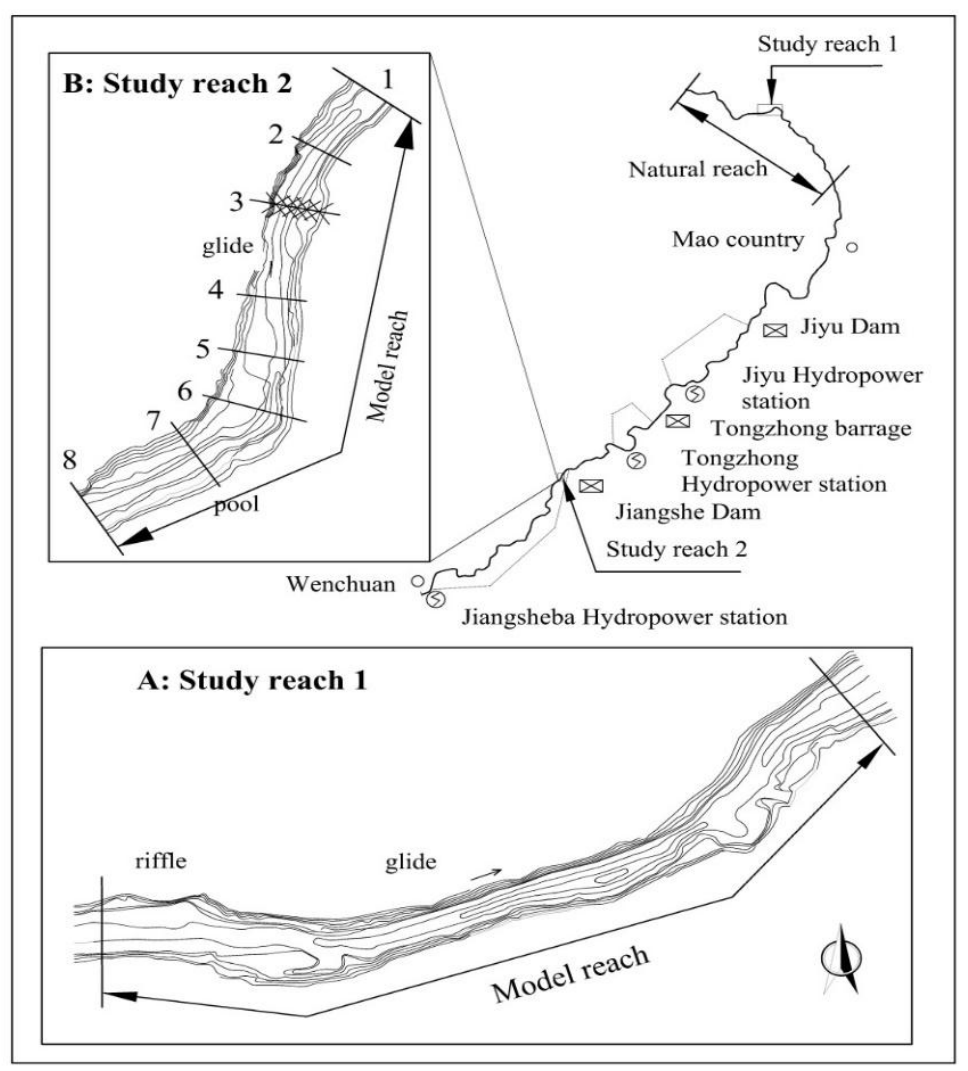

Figure 1 Map of the upper Min River catchment, located in the Yangtze River Basin, China; (A) Topographic survey of the studied reach showing the natural spawning model reach (study site 1, site length of $838.7 \mathrm{~m}$, gradient of 5.36\%o). (B) Topographic survey of the study reach showing the hydropower-affected study reach (length of $532.45 \mathrm{~m}$, gradient of $4.69 \%$ ). Sections $1 \sim 8$ are sites where the water surface elevation(WSE) was measured, and black crosses on Section 3 were sites where the depth and velocity were measured in study reach 2 . The complete topography of the study area, as measured in 2011, was provided by the Chengdu Engineering Corporation, Ltd..

\subsection{Substrate evaluation}

Evaluations of the substrate composition were conducted to estimate the mean size of the substrate $\left(D_{50}\right)$. We selected a site in study reach 2 and three sites in the natural spawning reach to investigate the substrate composition. Substrate samples were collected within a $1 \times 1 \times$ 0.5-m area at each location. For boulders and cobbles, the volume of a stone was determined 
based on measurements along three axes: A, the longest axis; $\mathrm{B}$, the intermediate axis; and $\mathrm{C}$, the shortest axis. The resulting equation for volume is $\bar{d}=\sqrt[3]{A^{*} B^{*} C}$, which was used for sand, gravel and pebbles after drying and weighing each component according to its class. Then, the sediment particle size distributions were calculated. Finally, a weighted average of the grain diameter was calculated for each combination of substrate size based on the following formula:

$$
d_{A}=\sum_{i=1}^{n} w_{i} d_{i}
$$

where $d_{A}$ is the mean diameter of the substrate; $d_{i}$ is the median value of the $i$-th class; $n$ is the number of classes identified at each observation point; and $w_{i}$ is the weight used according to the number of classes.

\subsection{Field measurements}

The locations of field measurements were downstream of the Jiangshe Dam, as shown in Figure 1. A propeller current meter (LS-501D, measurement range: $0.015 \sim 4 \mathrm{~m} / \mathrm{s}$, accuracy: $0.01 \mathrm{~m} / \mathrm{s}$ ) was used for the collection of velocity data. Velocity data were measured at 0.6 times the water depth. The water depth was measured with a depth meter; the accuracy was $0.01 \mathrm{~m}$ in the range of $2 \mathrm{~m}$. WSE was collected using a real-time kinetic (RTK) GPS unit with an accuracy of $0.02 \mathrm{~m}$.

Surveys of S. prenanti were conducted on March 26 and April 4, 2011 in the two study reaches. Fish surveys were mainly conducted with the assistance of local fishermen.

\subsection{Hydrodynamic model}

We simulated the hydraulic conditions in the natural spawning reach and restoration reach 
using River 2D, which is a two-dimensional (2D), depth-averaged model (Waddle, T. and P. Steffler. 2002 ; Steffler, P., and J. Blackburn. 2002 ; Steffler, P. 2002). The two output products calculated at each node of a triangulated irregular mesh for a given flow by River 2D are depth-averaged velocity and water depth.

The 2D governing equation for mass conservation is given by

$$
\frac{\partial H}{\partial t}+\frac{\partial q_{x}}{\partial x}+\frac{\partial q_{y}}{\partial y}=0
$$

Momentum conservations are given by

$$
\begin{aligned}
& \frac{\partial q_{x}}{\partial t}+\frac{\partial}{\partial x}\left(U q_{x}\right)+\frac{\partial}{\partial y}\left(V q_{x}\right)+\frac{g}{2} \frac{\partial}{\partial x} H^{2}=g H\left(S_{0 x}-S_{f x}\right)+\frac{1}{\rho}\left(\frac{\partial}{\partial x}\left(H \tau_{x x}\right)\right)+\frac{1}{\rho}\left(\frac{\partial}{\partial y}\left(H \tau_{x y}\right)\right) \\
& \frac{\partial q_{y}}{\partial t}+\frac{\partial}{\partial x}\left(U q_{y}\right)+\frac{\partial}{\partial y}\left(V q_{y}\right)+\frac{g}{2} \frac{\partial}{\partial y} H^{2}=g H\left(S_{0 y}-S_{f y}\right)+\frac{1}{\rho}\left(\frac{\partial}{\partial x}\left(H \tau_{y x}\right)\right)+\frac{1}{\rho}\left(\frac{\partial}{\partial y}\left(H \tau_{y y}\right)\right)
\end{aligned}
$$

where $H$ is the average depth; $U$ and $V$ are the average speeds along the $x$ and $y$ axes; $q_{x}$ and $q_{y}$ are the average discharges; $S_{0 x}$ and $S_{0 y}$ are the frictional slope values; $S_{f x}$ and $S_{f y}$ are the frictional resistance values; and $\tau_{x x}, \tau_{y y}, \tau_{x y}$ and $\tau_{y x}$ denote the horizontal shear stress in different directions.

To complete the formulation, a Boussinesq-type eddy viscosity is used to determine the transverse shear. Manning's roughness coefficient was determined based on the median size of the riverbed substrate obtained from the substrate evaluation (Leclerc, 1995).

$$
\begin{aligned}
& S_{f x}=\frac{\tau_{b x}}{\rho g H}=\frac{n^{2} U \sqrt{U^{2}+V^{2}}}{H^{4 / 3}} \\
& S_{f y}=\frac{\tau_{b y}}{\rho g H}=\frac{n^{2} V \sqrt{U^{2}+V^{2}}}{H^{4 / 3}}
\end{aligned}
$$




$$
\begin{gathered}
\tau_{x y}=v_{t}\left(\frac{\partial U}{\partial y}+\frac{\partial V}{\partial x}\right) \\
v_{t}=\varepsilon_{1}+\varepsilon_{2} \frac{H \sqrt{U^{2}+V^{2}}}{C_{s}}+\varepsilon_{3} H^{2} \sqrt{2 \frac{\partial U}{\partial x}+\left(\frac{\partial U}{\partial y}+\frac{\partial V}{\partial x}\right)^{2}+2 \frac{\partial V}{\partial y}}
\end{gathered}
$$

where $\varepsilon_{1}=0, \varepsilon_{2}=0.5, \varepsilon_{3}=0.1$. We limited our interpretation of the spatial scale to $1-5 \mathrm{~m}$ in the spatial discretization. Therefore, the flow domain of study site 1 was divided into 3792 triangular meshes, while the restoration reach was divided to 3019 elements.

The boundary conditions took a specified total discharge at inflow sections and a fixed WSE at outflow sections. Refer to file 1 for hydrodynamic boundary conditions. We conducted the steady-state habitat simulations over a flow range of $10 \mathrm{cms}$ (cubic meter per second) to $200 \mathrm{cms}$ with $10 \mathrm{cms}$ increments. Accordingly, a no-slip, stationary wall was adopted as the channel bed. However, the simulations were run as long as necessary to ensure that any errors associated with the initial conditions could be eliminated with this approach. To verify the River 2D model for the Min River, we followed the methodology and steps described at http://www.river2d.ualberta.ca and verified the surface water elevation downstream of Jiangshe Dam for monitored flow.

\subsection{Habitat similarity assessment model}

We used a cell-based habitat model and a vague set to calculate the weighted similarity area (WSA). First, vague sets of habitat variables were defined separately according to multi-expert opinions or measurement data (Eq.(12) and Eq.(13)). Second, using input variables from the hydraulic model (water depth, velocity), the vague set functions were employed to calculate the degree of membership of these variables (Eq.(12) and Eq.(13)). 
Third, the similarity of the vague sets (simulated set and ideal set) in each cell was calculated according to similarity rules (Eq.(14)). Fourth, as the physical habitat is described by more than one variable, we defined a composite similarity index to combine the individual similarity indices of each variable (Eq.(16)). Finally, the amount of WSA was computed by multiplying each cell area by its respective composite similarity index (Eq.(17) and Eq.(18)).

The vague set and similarity rules were established following Chen S.M. (Chen S.M, 1994, $1995,1997,2014)$. The state of the hydraulic habitat of fish spawning sites was described with a general index set $U$, that is equivalent to a specific set of hydraulic habitat indicators, $U=\{h, u\}$. The vague set and hesitation degree were described as follows (YE, J, 2007):

$$
\begin{array}{r}
v\left(x_{i}\right)=\left\{\left(x_{i},\left[t\left(x_{i}\right), 1-f\left(x_{i}\right)\right]\right)\right\} \\
\pi\left(x_{i}\right)=1-t\left(x_{i}\right)-f\left(x_{i}\right)
\end{array}
$$

where $t\left(x_{i}\right)$ is the true membership degree, which represents the attendance percentage of fishes; $f\left(x_{i}\right)$ is false membership degree, which represents the absence ratio of fishes; and $\pi\left(x_{i}\right)$ is the hesitation degree set member, which describes the level of uncertainty or imprecision in habitat modeling. $x_{i}=h_{i}, u_{i}$, and $i=1,2, \ldots, N$. Here, $N$ is the total number of sampled cells. Thus, a true membership for $x_{i}$, (i.e., $t\left(x_{i}\right)=1$ and $\left.f\left(x_{i}\right)=0\right)$ necessarily implies that $x_{i}$ is a suitable value and that all experts support this value. As a result, fish spawning is expected to occur under these circumstances. An alternative case is when there is a moderate indication of support (i.e., $t\left(x_{i}\right)=0.5$ ) combined with weak evidence of opposition (i.e., $f\left(x_{i}\right)=0.1$ ), then the hesitation degree is $\pi\left(x_{i}\right)=0.4$.

Vague sets for each input variable were defined by simple trapezoidal or triangular 
membership functions (Ahmadi-nedushan, et al., 2006). The boundary values were based on expert opinion in the literature. Chen $(2012,2013)$ proposed a preferred water depth range of $1.18-1.8 \mathrm{~m}$ and a current speed of $1.27-2.02 \mathrm{~m} / \mathrm{s}$ based on a frequency analysis of hydraulic simulation results for S. prenanti spawning habitat. Lu (2012) suggested a preferred water depth range of $0.5-1.5 \mathrm{~m}$ and a current speed of $1.5-2.5 \mathrm{~m} / \mathrm{s}$ based on consultation with experts. Additionally, the Institute of Hydro-ecology, MWR and CAS (Chen, 2012) proposed a water depth range of $0.8-1.5 \mathrm{~m}$ and a current speed range of $0.5-1.5 \mathrm{~m} / \mathrm{s}$ based on investigations of natural spawning habitat reaches. The membership functions of $u_{i}$ and $h_{i}$ are defined as Eq. (12) and Eq. (13).

$$
\begin{aligned}
& \left\{\left\{\left(u_{i},[0,0]\right)\right\} \quad: u_{i} \leq 0.5, u_{i}>2.5\right. \\
& \left\{\left(u_{i},\left[\frac{u_{i}-0.5}{1.65-0.5}, \frac{u_{i}-0.5}{1.27-0.5}\right]\right)\right\}: 0.5<u_{i} \leq 1.27 \\
& v\left(u_{i}\right)=\left\{\left\{\left(u_{i},\left[\frac{u_{i}-0.5}{1.65-0.5}, 1\right]\right)\right\}: 1.27<u_{i} \leq 1.65\right. \\
& \left\{\left(u_{i},\left[\frac{2.5-u_{i}}{2.5-1.65}, 1\right]\right)\right\}: 1.65<u_{i} \leq 2.02 \\
& \left\{\left(u_{i},\left[\frac{2.5-u_{i}}{2.5-1.65}, \frac{2.5-u_{i}}{2.5-2.02}\right]\right)\right\}: 2.02<u_{i} \leq 2.5
\end{aligned}
$$

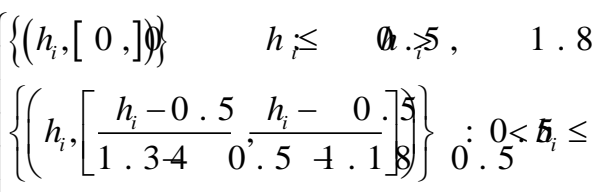

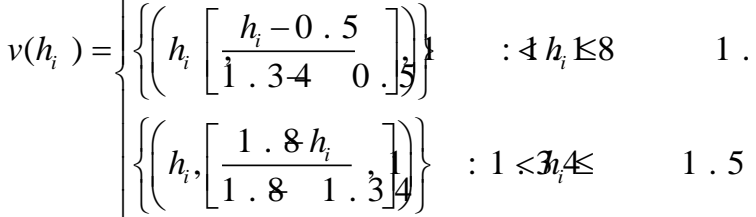

$$
\begin{aligned}
& \left\{\left(h_{i},\left[\frac{1.8 h_{i}}{1.81 .34}, \frac{1.8-h_{i}}{1.8-1.34}\right]\right)\right\}: 1.5<h_{i} \leq 1.8
\end{aligned}
$$



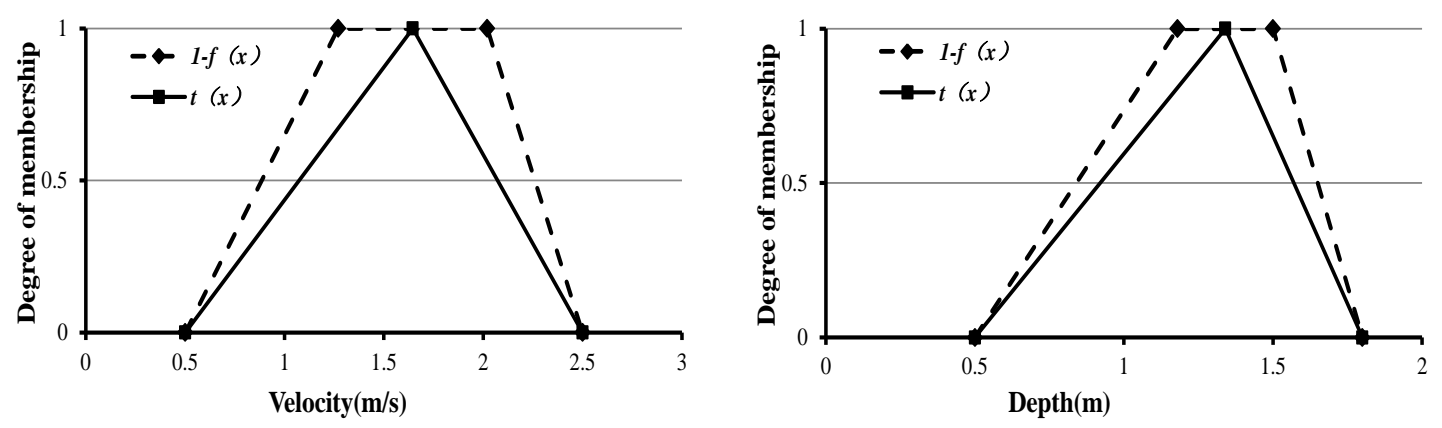

Figure 2 Membership functions for water velocity and depth.

Similarity measurements of vague sets are defined based on the concept of distance. The similarity between the simulated vague sets, $v_{A}\left(x_{i}\right)=\left\{\left(x_{i},\left[t_{A}\left(x_{i}\right), 1-f_{A}\left(x_{i}\right)\right]\right)\right\}$, and the ideal vague set, $v_{B}\left(x_{I}\right)==\left\{\left(x_{I},[1,1]\right)\right\}$, was expressed as follows (Zhou, 2005; Li, 2002):

$$
T(A, B)=1-\frac{\left|t_{A}\left(x_{i}\right)-t_{B}\left(x_{I}\right)-\left(f_{A}\left(x_{i}\right)-f_{B}\left(x_{I}\right)\right)\right|}{4}-\frac{\left|t_{A}\left(x_{i}\right)-t_{B}\left(x_{I}\right)\right|+\left|f_{A}\left(x_{i}\right)-f_{B}\left(x_{I}\right)\right|}{4}
$$

Where $T(A, B) \in[0,1]$. Larger values of $T(A, B)$ indicate greater similarity between $v_{A}\left(x_{i}\right)$ and $v_{B}\left(x_{I}\right)$.

The physical habitat is dependent on multi-variables (e.g., depth, velocity), we defined a composite similarity index (S) to combine the separate similarities of physical variables. Finally, we added a weighting function (Eq.(15) and Eq.(16)) to represent relative importance. The weight of each preference index was denoted by the respective exponent $\alpha_{i}$, where $\alpha_{h}=0.4, \alpha_{u}=0.6$ :

$$
\begin{gathered}
\sum \alpha_{i}=1, \\
S_{i}=\sqrt{\alpha_{h} T_{h}^{2}+\alpha_{u} T_{u}^{2}}
\end{gathered}
$$

The WSA was computed by multiplying each cell area $\left(A r e a_{i}\right)$ by S. Finally, the weighted similarity $(P)$ was obtained by dividing the WSA by the total area $\left(\sum_{i=1}^{n}\right.$ Area $\left._{i}\right)$, as shown in Eq. 
(17) and Eq. (18). Reaches with higher similarities are more suitable as fish habitats:

$$
\begin{gathered}
W S A=\sum_{i=1}^{n} \text { Area }_{i}^{*} S_{i}, \\
P=W S A / \sum_{i=1}^{n} \text { Area }_{i},
\end{gathered}
$$

\section{Results and discussion}

\subsection{Substrate composition analysis}

Substrate samples of $1 \times 1 \times 0.5 \mathrm{~m}$ were collected in each of the following areas: (A) a region of riverbed in the middle of the river (cumulative weight of $858.8 \mathrm{~kg}$, maximum particle size of $250 \times 200 \times 130 \mathrm{~mm}$, and $\mathrm{D}_{\max }=187 \mathrm{~mm}$ ); (B) a region of riverbed along the riverside (cumulative weight of $765.4 \mathrm{~kg}$, maximum particle size of $470 \times 270 \times 170 \mathrm{~mm}$, and $\mathrm{D}_{\max }=278$ $\mathrm{mm}$ ); and (C) a region of riverbed near Weimen Township (cumulative weight of $753.1 \mathrm{~kg}$, maximum particle size of $300 \times 300 \times 70 \mathrm{~mm}$, and $\left.\mathrm{D}_{\max }=185 \mathrm{~mm}\right)$.

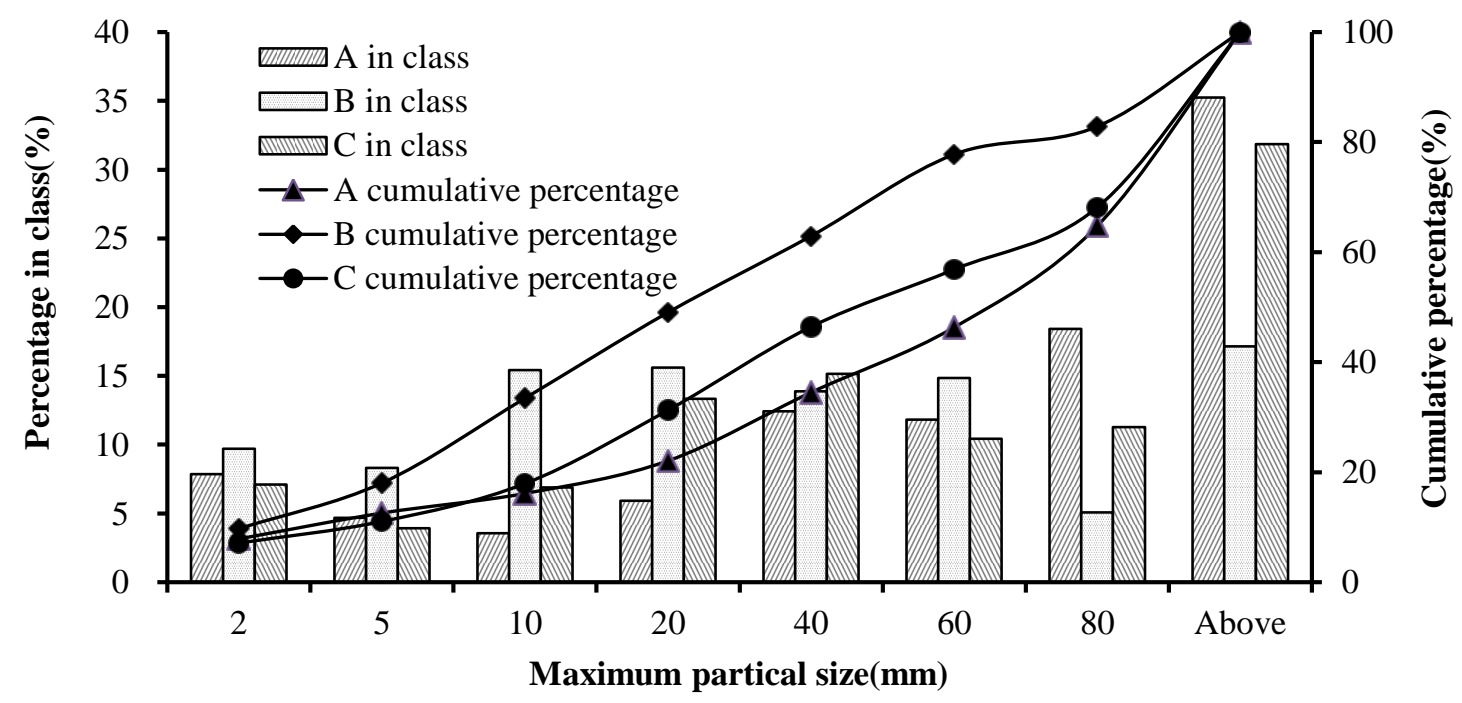

Figure 3 Representative particle size composition in the selected reach of the natural spawning reach (A, in the middle of the river $\left(31.83^{\circ} \mathrm{N}, 103.68^{\circ} \mathrm{E}\right)$; $\mathrm{B}$, along the riverside $\left(31.73^{\circ} \mathrm{N}, 103.71^{\circ} \mathrm{E}\right)$; and $\mathrm{C}$, a 
region of riverbed near Weimen Township $\left.\left(31.75^{\circ} \mathrm{N}, 103.81^{\circ} \mathrm{E}\right)\right)$.

The riverbed was covered with cobbles $(64-256 \mathrm{~mm})$ and pebbles $(4-64 \mathrm{~mm})$ and occasional boulders $(>256 \mathrm{~mm})$, with sand $(<2 \mathrm{~mm})$ and granules $(2-4 \mathrm{~mm})$ filling the spaces between the larger components. The substrate composition of this natural ecological reserve reach provides a standard reference composition for other restoration projects. Using Eq.(1), the mean diameter of the sampled substrate in Weimen township (the selected natural spawning reach) was found to be $52.28 \mathrm{~mm}$; therefore, according to Leclerc, Manning's roughness coefficient for a natural spawning riverbed is 0.041(Leclerc, 1995).

In the restoration reach downstream from the Jiangshe Dam, the riverbed was largely covered with cobbles and boulders, with a substrate sample cumulative weight of $858.8 \mathrm{~kg}$, a maximum particle size of $250 * 200 * 130 \mathrm{~mm}$, a $D_{\max }=187 \mathrm{~mm}$, a mean substrate diameter of $125.7 \mathrm{~mm}$, and a Manning's roughness coefficient of 0.05 (Leclerc, 1995).

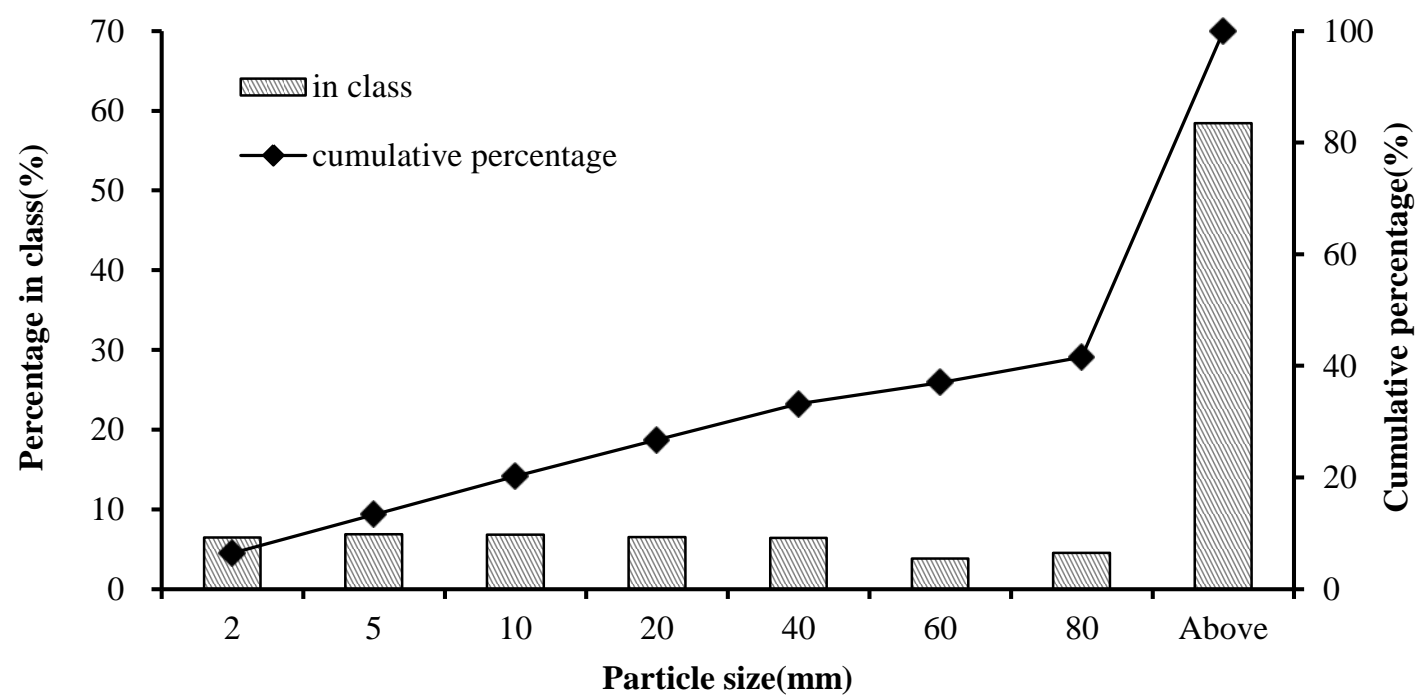

Figure 4 Representative particle size composition in the restoration reach. (Study reach $2,31.55^{\circ} \mathrm{N}$, $\left.103.68^{\circ} \mathrm{E}\right)$ 


\subsection{Survey of $S$. prenanti}

The survey of $S$. prenanti in the upper Min River revealed that the spawning grounds for $S$. prenanti are centered on the junction between the Heishui tributary to the Min River and the reaches from Feihong to Weimen Township. This natural reach exhibits a high species richness and abundance of native fishes. Among all of the fishes collected in this natural reach, $S$. prenanti showed the highest abundance and contributed $88 \%$ of the total weight. The largest $S$. prenanti individual collected was approximately $850 \mathrm{~g}$, while the average weight of $S$. prenanti individuals was $197 \mathrm{~g}$ (range, approximately $40-850 \mathrm{~g}$ ), and the average length was $21.5 \mathrm{~cm}$ (range, approximately $13.0-35.5 \mathrm{~cm}$ ). However, we were unable to catch any $S$. prenanti individuals downstream of the Jiangshe Dam. The habitat quality of the reaches from Feihong to Weimen Township (natural habitat reach) is better than that downstream of the Jiangshe Dam (hydroelectric-affected reach).

\subsection{Hydrodynamic modeling}

The hydrodynamic model simulates the influence of topography, substrate composition and discharge on a spawning habitat. The current velocity and depth maps of the natural spawning site based on the averaged flow rate $(106.5 \mathrm{cms})$ are shown in Figure 5(A), where the maximum velocity was $3.0 \mathrm{~m} / \mathrm{s}$, and the maximum depth was $6.2 \mathrm{~m}$. The corresponding maps of the restoration reach are shown in Figure 5(B); the maximum velocity was $1.9 \mathrm{~m} / \mathrm{s}$, and the maximum depth was $5 \mathrm{~m}$.

We regarded the results of the simulations as substitute data for direct measurements of these parameters. That provided flexible results for aquatic habitat assessment in situations in 
which direct monitoring or any general observations of river conditions are unfeasible. A given water depth provides the necessary volume for protection against predators and a sufficient area for foraging. A given current speed may stimulate brood stock to lay eggs and can favor the growth of fish eggs. For these reasons, we selected water depth and velocity as parameters for assessing the habitat similarity. Other physical variables could be studied in the future, such as the depth ratio, Froude number and vorticity (Ian and Jowett, 1993; Sempeski and Gaudin, 1995, Armstrong et al., 2003; Louhi et al., 2008; Rosenfeld et al., 2011).

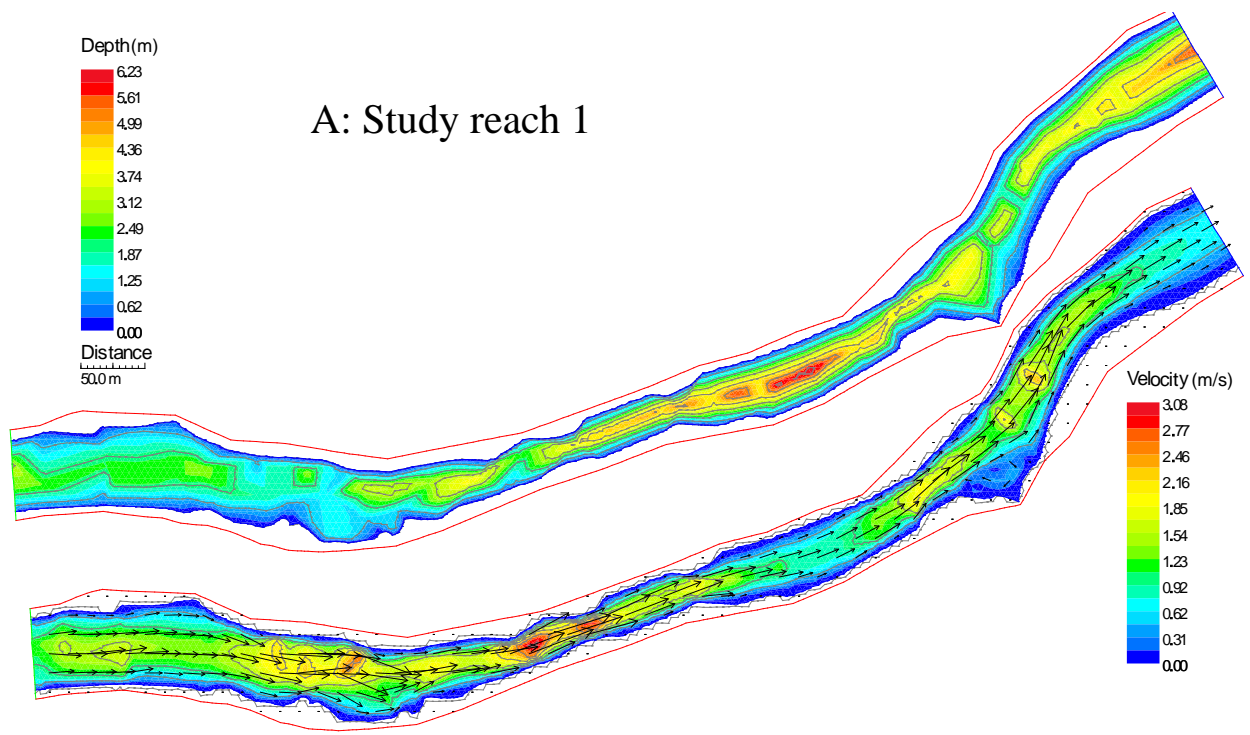




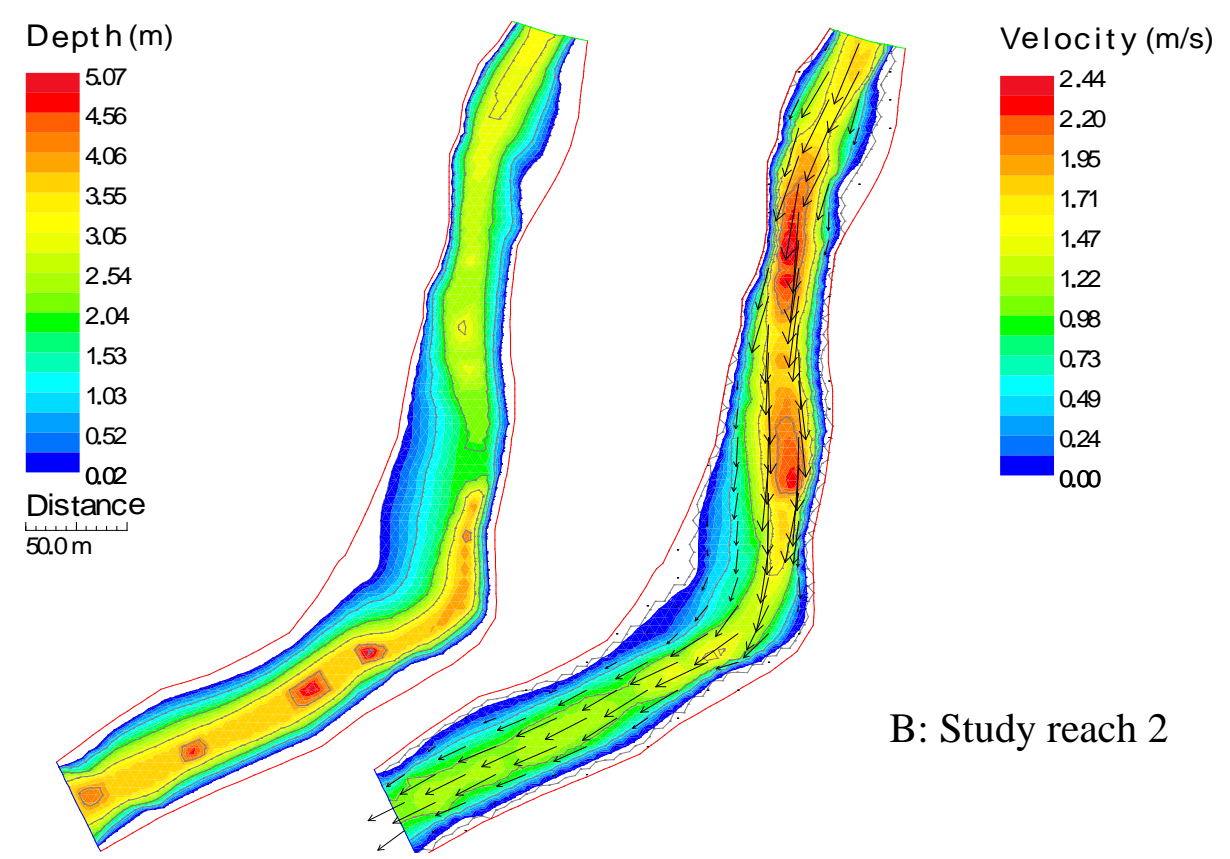

Figure 5 Velocity field distribution and depth maps for (A) the natural habitat reach and (B) the restoration reach, for a flow of $106 \mathrm{cms}$.

\subsection{Model verification}

We measured water depth and current velocity at five points in section 3 in study reach 2 , as shown in Figure 1, and compared the data from the simulated results with the discharges observed in the study reach 2 . We calibrated the hydrodynamic model by adjusting the mesh to achieve closer agreement between the simulated and measured water-surface elevations and water velocities. We were unable to obtain any measurements in the natural habitat reach for use in validating the simulation results. Furthermore, we relied exclusively on the calibration of the observed discharge and the depth-averaged equations to reach equilibrium (inflow equals outflow) for each simulation. The two-dimensional hydraulic simulations for velocity and depth yielded accuracies of approximately $84-97 \%$ and $81-98 \%$, respectively (Figure 7). Monitored WSE was calibrated according to WSE results output by River2D, the maximum difference of monitored and simulated WSE was $-0.06 \mathrm{~m}$. In a previous study, Hatten verified 
the River 2D model of Plummer, Pedersen and Apscar. Springbrooks achieved velocity and depth accuracies of approximately 74-91\% (RMSE) and 84-92\%, respectively (Waddle, T. 2009; Ghanem, 1995; LEE, J H, et al., 2010, Hatten, J. R., 2013).

The uncertainty in the numerical simulation was related to geometry, boundary conditions and Manning's roughness coefficient. We conducted sensitivity analysis for the model based on the test case of study reach 2 ; we statistically assessed the velocity and depth distribution in section 3. Manning's roughness coefficient was equal to 0.05 ; the mesh sizes were 2,5 and 10 $\mathrm{m}$; the maximum depths of section 3 were $2.33,2.39$ and $2.76 \mathrm{~m}$, respectively, and the corresponding average depths were $1.43,1.51$ and $1.72 \mathrm{~m}$. The results for the $2 \mathrm{~m}$-mesh size were closer to those for the $5 \mathrm{~m}$-mesh size, and we conducted our simulation using the 5 m-mesh size. When the mesh size was $5 \mathrm{~m}$, Manning's roughness coefficients were $0.04,0.05$ and 0.06 ; the average depths of section 3 were $1.42,1.51$ and $1.59 \mathrm{~m}$; and the maximum depths were $2.19,2.38$ and $2.37 \mathrm{~m}$, respectively. We selected this coefficient according to the mean diameter of the substrate based on the results of substrate evaluation.

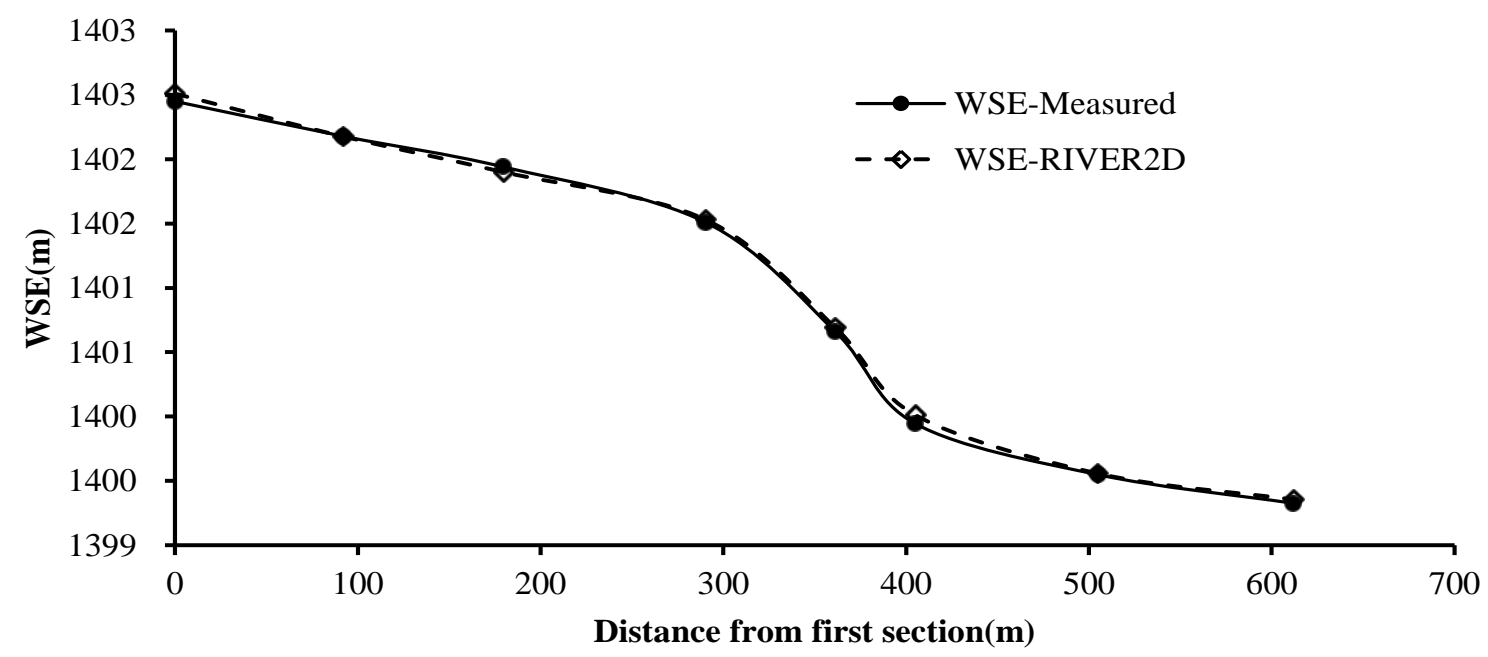

Figure 6 Verification of the hydrodynamic model for the restoration habitat reach at a $0.17 \mathrm{cms}$ flow. 
Elevations were collected with a real-time kinetic (RTK) GPS unit with an accuracy of $0.02 \mathrm{~m}$, calibrated according to the WSE results output by River2D.
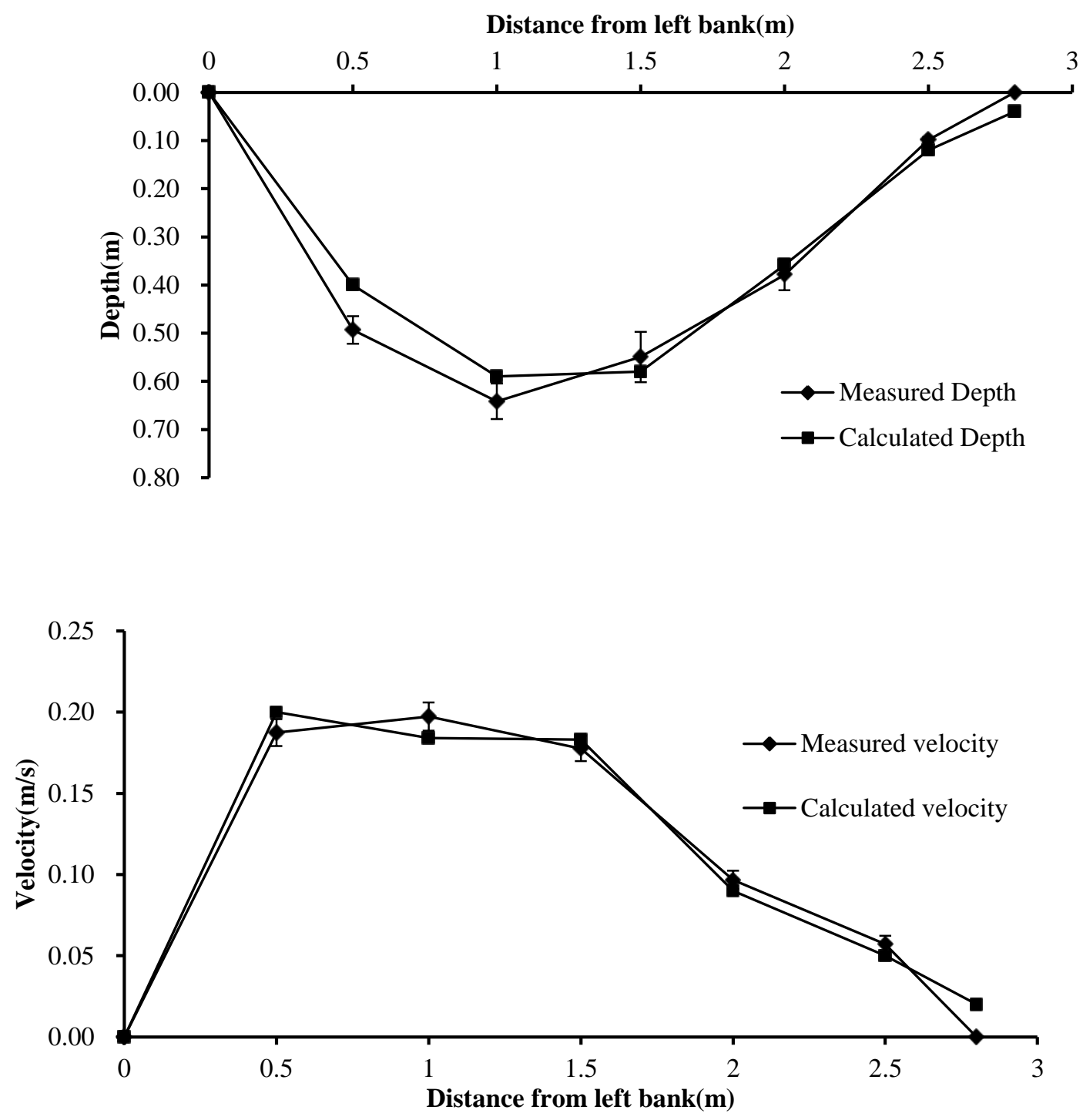

Figure 7 Depth and velocity distribution profiles for restoration habitat reach section 3, at a flow rate of $0.17 \mathrm{cms}$, as simulated by River2D or obtained with the propeller current meter. Measured data are shown as the mean $\pm \operatorname{SD}(\mathrm{n}=3)$.

\subsection{Habitat similarity model}

Using the results from the hydrodynamic model, patches of the study reach were characterized according to the weighted similarity index. We simulated weighted similarities over a flow range of $10-200 \mathrm{cms}$ with $10 \mathrm{cms}$ flow increments; the results are shown in Figure 8. 
In addition, the respective $\alpha_{i}$ exponents in the weighting function (Eq. (15) and Eq. (16)) represent the relative importance of the physical variables. Guay (Guay J. C., 2000, 2003) defined the exponents for water depth, current velocity and substrate size as $0.30,0.38$, and 0.32, respectively, based on statistical data. According to a survey of S. prenanti in Yangtze River (Wang Y.R., 2010), S. prenanti is more sensitive to velocity than to water depth. Therefore, we defined $\alpha_{h}=0.4$, and $\alpha_{u}=0.6$.

The weighted similarity is increased by increasing the flow. However, when the flow volume exceeds the critical value, both water depth and velocity will exceed the suitable ranges. Adult fishes cannot tolerate excessive velocities, and fish eggs are readily flushed from the substrate, while excessive water depths have negative effects on egg hatching. As a result, the weighted similarity will decrease when the flow exceeds the critical range. In the case studies, weighted similarity has been shown to increase with the flow up to a threshold range of approximately $130-150 \mathrm{cms}$ beyond which the weighted similarity decreases. Therefore, to protect the quality of $S$. prenanti spawning habitat, a threshold ecological flow for the spawning season might be $130-150 \mathrm{cms}$.

We conducted surveys of $S$. prenanti in the natural habitat reach and the reach downstream of the Jiangshe Dam and regarded the two reaches separately. In the study reach 2, the weighted similarity corresponding to the monitored flow rate was lower than 0.1 ; the usable habitat area was extensively reduced. The absence of $S$. prenanti from this reach in the surveys is consistent with these results. In contrast, the natural habitat reach with flow of $85 \mathrm{cms}$ exhibited a better spatial heterogeneity and provide a better habitat for $S$. prenanti spawning. 
The corresponding weighted similarity was 0.5 , which was significantly higher than that of the restored reach. The high species richness of fishes and abundance of fish resources observed in this study support this conclusion.

The weighted similarity of the natural habitat reach was better than that of the restored reach at the same flow volume. Because the curvature of the natural habitat reach is greater than that of the restored reach, suitable beaches are readily formed in the natural reach during floods. If weighted similarity must be further improved in the reach, structural protection measures can be implemented, such as placement of hydraulic structures for substrate enhancement.

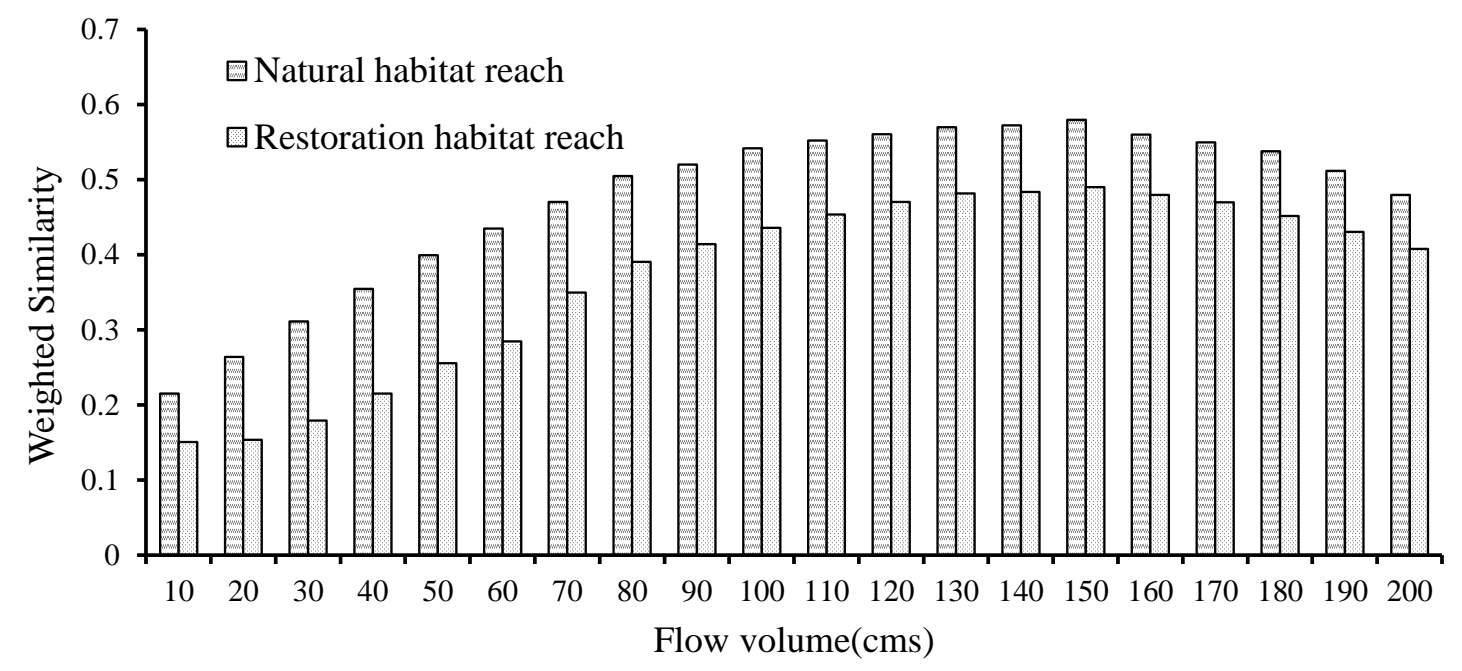

Figure 8 Weighted similarity-flow volume relationships for the natural habitat reach and restoration habitat reach, over a flow volume range of 10 200 cms, with $10 \mathrm{cms}$ increments.

\section{Conclusion}

We combined River 2D, which predicts local variations in depth and velocity at a given flow, and a vague-based similarity evaluation that assesses habitat quality for fish using 
hydraulic indexes to assess the potential effects of a reduced flow volume on the S. prenanti spawning habitat area in downstream of dams. The innovative aspects of this work are as follows: (a) the use of vague sets to simultaneously define spawning habitat presence/absence and uncertainty in the data and to comprehensively consider knowledge from multiple experts, wherein the vague sets were regarded as an alternative to traditional habitat suitability curves, which only describe absence information; and (b) the establishment of a habitat similarity model based on vague sets to evaluate $S$. prenanti spawning habitat by comparing simulated sets with an ideal set $[1,1]$. The results regarding habitat similarity may provide flow volume thresholds for $S$. prenanti spawning habitat areas to help managers develop a proactive conservation strategy for wetland management. Future research will be aimed at completing the collection of preference information and considering the influence of other physical variables in the model, such as temperature, the current velocity gradient, vorticity, and water quality indexes.

\section{Acknowledgments}

We are grateful to the Chengdu Engineering Corporation, Ltd., for providing the topographic information. Funding for this research was partially provided by the National Natural Science Foundation of China (No. 51479127 and No. 51279114).

Ben R. Hodges was partially supported by the U.S. National Science Foundation through Grant No. CCF-1331610 and the Open Fund of the State Key Laboratory of Hydraulics and Mountain River Engineering, SKHL1304. 


\section{References}

Ahmadi-Nedushan, B., St-Hilaire, A., Bérubé, M., Ouarda, T. B. M. J. and Robichaud, É., 2008. Instream flow determination using a multiple input fuzzy-based rule system: a case study. River Res. Applic., 24:279-292. DOI:10.1002/rra.1059.

Ahmadi-Nedushan, B., St-Hilaire, A., Bérubé, M., Robichaud, É., Thiémonge, N. and Bobée, B., 2006. A review of statistical methods for the evaluation of aquatic habitat suitability for instream flow assessment. River Res. Applic., 22:503-523. DOI:10.1002/rra.918.

Armstrong, J., Kemp, P.S., Kennedy, G.J.A., Ladle, M. and Milner, N.J., 2003. Habitat requirements of Atlantic salmon and brown trout in rivers and streams. Fisheries Research, 62, (2), 143-170. DOI: 10.1016/S0165-7836 (02)00160-1.

Bovee, K.D., 1986. Development and evaluation of habitat suitability criteria for use in the instream flow incremental methodology. Washington, DC: USDI Fish and Wildlife Service. 235p.

Chen, M.Q., 2012. Study on Hydraulic Characteristics of Schizothorax Prenanti Spawning Ground in the Upper Reach of Minjiang River and its Application. Ph.D.Thesis, ChengDu: Sichuan University.

Chen M.Q., Tuo Y.C., Li Jia, Wang Q.G., 2013. Preliminary study on index system describing hydraulic characteristics of fish spawning ground. J. Hydraul. Eng., 44(11). (In Chinese)

Chen S.M., Tan J.M., 1994. Handing multi criteria fuzzy decision-making problems based on vague set theory. Fuzzy Set Syst., 67(2):163-72.DOI:10.1016/0165-0114 (94)90084-1.

Chen S.M., 1997. Similarity measures between vague sets and between elements. IEEE T. Syst. Man Cy. $B, 27(1): 153-158$.

Chen S.M., 1997.Measures of similarity between vague sets. Fuzzy Set Syst., 1995, 74(2): 217-223. 
Chen S.M., Hong J.A., 2014. Multicriteria linguistic decision making based on hesitant fuzzy linguistic term sets and the aggregation of fuzzy sets, Inform. Sciences, 286: 63-74, DOI:org/10.1016/j.ins.2014.06.020.

Ding, R.H., 1994. The fishes of Sichuan, China. Sichuan Publishing House of Science and Technology, Chengdu, Sichuan, China, p 641 (in Chinese).

Dong Z.R., 2007. Principles and technologies of eco-hydraulic engineering. China Water Power Press, Beijing.

Fukuda S., De Baets B., Mouton A.M., Waegeman W., Nakajima J., Mukai T., Hiramatsu K., Onikura N., 2011. Effect of model formulation on the optimization of a genetic Takagi-Sugeno fuzzy system for fish habitat suitability evaluation. Ecol. Model., 222(8): 1401-1413. DOI: 10.1016/j.ecolmodel.2011.01.023.

Gau, W.L.; Buehrer D.J., 1993. Vague sets. IEEE T. Syst. Man Cy., 23(2):610-614. DOI: 10.1109/21.229476.

Guay J.C., Boisclair D., Leclerc M., Lapointe M., 2003. Assessment of the transferability of biological habitat models for Atlantic salmon parr (Salmo salar). Can. J. Fish. Aquat. Sci., 60(11): 1398-1408. DOI: $10.1139 / \mathrm{F} 03-120$.

Guay J.C., Boisclair D, Rioux D, Leclerc M, Lapointe M, Legendre P., 2000. Development and validation of numerical habitat models for juveniles of Atlantic salmon (Salmo salar). Can. J. Fish. Aquat. Sci., 57(10): 2065-2075. DOI: 10.1139/cjfas-57-10-2065.

Ghanem A.H., Steffler P.M., Hicks F.E., Katopodis, C., 1995. Two dimensional finite element flows model for aquatic habitats. Ph.D.Thesis, University of Alberta, Canada. 
Hatten, J. R., Batt, T. R., Scoppettone, G. G., \& Dixon, C. J. 2013. An ecohydraulic model to identify and monitor moapa dace habitat. Plos One, 8(2), e55551.

Hou B.D., Zhu X.X., Liang C., 2010. Water environment cumulative impact of cascade hydropower development in upper typical reach. Yangtze River, 41(7): 32-37. (In Chinese)

Hong D.H., Choi C.H., 2000. Multi criteria fuzzy decision-making problems based on vague set theory. Fuzzy set. Syst., 114(1):103-13.doi:10.1016/S0165-0114 (98)00271-1.

Ian G. Jowett, 1993. A method for objectively identifying pool, run, and riffle habitats from physical measurements, New Zeal. J. Mar. Fresh., 27:2, 241-248, DOI: 10.1080/00288330.1993.9516563.

Jorde K, Schneider M, Peter A, Zoellner F. 2001. Fuzzy based models for the evaluation of fish habitat quailty and instream flow assessment. Proceedings of the 3rd International Symposium on Environmental Hydraulics. 3:27-28.

Lee J H, Kil J T, Jeong S. 2010. Evaluation of physical fish habitat quality enhancement designs in urban streams using a 2D hydrodynamic model.Ecol. Eng., 36(10): 1251-1259.

Lee L.W., Chen S.M., 2014. Fuzzy decision making based on likelihood-based comparison relations of hesitant fuzzy linguistic term sets and hesitant fuzzy linguistic operators, Inform. Sciences, 294: 513-529, ISSN 0020-0255.DOI:org/10.1016/j.ins.2014.09.061.

Li DF, Cheng CT, 2002. New similarity measures of intuitionistic fuzzy sets and application to pattern recognitions. Pattern Recogn. Lett. 23(1): 221-225. DOI: 10.1016/S0167-8655(01)00110-6.

Leclerc M., Boudreault A., Bechara J.A., Corfa G., 1995. Two-Dimensional Hydrodynamic Modeling: A Neglected Tool in the Instream Flow Incremental Methodology. T. Am. Fish. Soc. 124(5): 645-662. DOI: 10.1577/1548-8659(1995)124<0645:TDHMAN>2.3.CO;2. 
Lu, H.W., 2012. Study on ecological flow based on the fish habitat evaluation method in mountainous river. Chengdu: Sichuan University.

Louhi, P., Mäki-Petäys, A. and Erkinaro, J., 2008. Spawning habitat of Atlantic salmon and brown trout: general criteria and intragravel factors. River Res. Applic., 24:330-339. doi:10.1002/rra.1072.

Milhous, R.T., Wegner, D.L., Waddle, T., 1984. User's guide to the physical habitat simulation system (PHABSIM). Department of the Interior, US Fish and Wildlife Service.

Marsili-Libelli, S., Giusti, E., Nocita, A., 2013. A new instream flow assessment method based on fuzzy habitat suitability and large scale river modeling. Environ. Modell. Softw., 41: 27-38. DOI:10.1016/j.envsoft.2012.10.005.

Mocq, J., St-Hilaire, A., Cunjak, R.A., 2015. Influences of Experts' Personal Experiences in Fuzzy Logic Modeling of Atlantic Salmon Habitat. N. Am. J. Fish Manage., 35(2): 271-280. DOI:10.1080/02755947.2014.996684.

Moir, H.J., Gibbins, C.N., Soulsby, C., Youngson, A.F., 2005. PHABSIM modelling of Atlantic salmon spawning habitat in an upland stream: testing the influence of habitat suitability indices on model output. River Res. Applic., 21(9): 1021-1034. DOI: 10.1002/rra.869.

Rosenfeld, J.S., Campbell, K., Leung, E.S., Bernhardt, J., Post, J., 2011. Habitat effects on depth and velocity frequency distributions: Implications for modeling hydraulic variation and fish habitat suitability in streams. Geomorphology, 130(3): 127-135.DOI: org/10.1016/j.geomorph.2011.03.007. Sempeski, P., Gaudin, P., 1995. Habitat selection by grayling-I. Spawning habitats. J. Fish Biol., 47(2): 256-265. DOI: 10.1111/j.1095-8649.1995.tb01893.x. 
Steffler, P., and J. Blackburn. 2002. River2D. Two-Dimensional Depth Averaged Model of River Hydrodynamics and Fish Habitat. Introduction to Depth Averaged Modeling and User's Manual. University of Alberta. September. Available online at http:// www.river2d.ualberta.ca/ software/ River2D.pdf (accessed on 1 October 2009).

Steffler, P. 2002. R2D_Bed, Bed Topography File Editor User's Manual: Edmonton, University of Alberta. Available online at http://www.river2d.ualberta.ca/software/R2D_Bed.pdf (accessed 30 September 2009).

Song Z, Song J, Yue B. 2008. Population genetic diversity of Prenant's schizothoracin, Schizothorax prenanti, inferred from the mitochondrial DNA control region. Environ. Biol. Fishes, 81(3): 247-252.

Tharme R E. 2003. A global perspective on environmental flow assessment: emerging trends in the development and application of environmental flow methodologies for rivers. River Res. Appl., 19(5-6): 397-441.

Wheaton, J.M., Pasternack, G.B., Merz, J.E., 2004 a. Spawning habitat rehabilitation-I. Conceptual approach and methods. Intl. J. River Basin Management, 2(1): 3--20.

Wheaton, J.M., Pasternack, G.B., Merz, J.E., 2004 b. Spawning habitat rehabilitation-II. Using hypothesis development and testing in design, Mokelumne River, California, USA. Intl. J. River Basin Management, 2(1): 21--37.

Waddle, T. and P. Steffler. 2002. R2D_Mesh, mesh generation program for River2D two dimensional depth averaged finite-element hydrodynamic simulation-Introduction to mesh generation and 
users's manual. Available online at http://www.river2d.ualberta.ca/software/R2d_mesh.pdf (accessed 30 September 2009).

Waddle, T., P. M. Steffler, A. Ghanem, C. Katopodis, and A. Locke. 1996. Comparison of one and two dimensional hydrodynamic models for a small habitat stream. Ecohydraulics 2000: Proceedings of the 2nd International Symposium on Habitat Hydraulics, Quebec City.

Waddle, T. 2010. Field evaluation of a two-dimensional hydrodynamic model near boulders for habitat calculation. River Res. Appl. 26:730-741.DOI: 10.1002/rra.1278.

Wang, Y.R.,TAN, Y.P.2010. Initial analysis of hydraulic characteristics of natural S. prenanti habitat. Sichuan Water Resources.(6):55-59.(in Chinese).

Ye, J., 2007. Improved method of multicriteria fuzzy decision-making based on vague sets. Compute Aided Design, 39(2): 164-169. DOI:10.1016/j.cad.2006.11.005.

Yang, Y., Yan, Z.M., Chang, J.B., 2007. Computation and analysis of the cross-section mean vorticity in Chinese sturgeon spawning area. Advances in Water Science, 18(5):701-705. (In Chinese).

Zhou X.G., Z.Q., 2005. Comparison and improvement on similarity measures between vague sets and between elements. Journal of Systems Engineering, 20(6): 613--619. (In Chinese).

Zadeh L.A., 1965. Fuzzy sets. Information and Control, 8(3): 338-353. DOI: 10.1016/S0019-9958(65)90241-X. 